\title{
The protection of migrant children in the European Union: a reading in the light of the Committee on the Rights of the Child's General Comment (Nos.22 and 23) on the rights of the children in the context of the international migration
}

\author{
NIberto D. ARRUFAT CARDAIN
}

\begin{abstract}
Ibstract: The article analy ses the evolution of the international regulation of human rights by migrants with special attention to the adoption of general observations 22 and 23 on the rights of the child within the framework of international migration of the Committee on the Rights of the Child drafted together to the Committee on the rights of migrant workers and their families. Since 2013 , the number of children, especially foreign unacempanied children who have reached the territory of the European Union, has increased exponentially. The European legislator, involved in an unprecedented migration crisis, has made an important effort to adapt its regulations to the obligations established by the International Law of IIuman Rights; however, incompatible and chiaroscuro approaches remain in regulation.
\end{abstract}

Keywords: General Comment 22 and 23 Committee on the rights of the Child - Migrant child, migrant worker - unaceompanied child, unaccompanied minor - refugee - Regulation Dublin III - Proposal Dublin IV Regulation - disembarkation platforms

\section{( I) MIGR ITT CIILDRE\IX TIIECURRE\TCONTEXT}

Children separated from their parents by expiry of visas, abandoned on a ship without government by the Mediterranean; trafficked to be drugged and their organs removed'. It might seem that the Committee on the Rights of the Child had a premonition when, just three months before 2018, annus horribilis for the Rights of the Child, it published the Committee on the Rights of the Child's Joint General Comment No. 22 on the general principles relating to the human rights of children in the context of international migration, ${ }^{2}$ and the Committee on the Rights of the Child's Joint General Comment No. 23 on states' obligations regarding the human rights of children in the context of international migration in countries of origin, transit, destination and return. ${ }^{3}$

Unfortunately, this was not the case, since the problem of migrant children is not current, although in recent limes it has reached dramatic levels.

One of the most relevant aspects of the migratory phenomenon is its evolution: since 2005 it has

\footnotetext{
as trlicle published on.31 December 2019

Issociate Professor of International Law and European Union Law. Jean Monnet Chair. Universidad Católica de Valencia. ad.arrufat $a_{\text {ucv.es. }}$

U NICEF, A Deadly Journey for Children. The Central Mediterranean Migration Route`, ( M C, 2orz). Electronic text available here, accessed 25 Jull 2019 .

2 Joint General Comment Vo.3 (2017) of the Committee on the Protection of the Rights of All Migrant Workers and Members of Their Families and Vo. 22 (2017) of the Committee on the Rights of the Child on the general principles regarding the human rights of the international migration, CRC/C. GC/22, Electronic text available here, accessed 25 July 2019.

3. Joint General Comment Vo. 4 (2017) of the Committee on the Protection of the Rights of All Migrant Workers and Members of Their Families and Vo. 23 (2017) of the Committee on the Rights of the Child on State obligations regarding the human rights of child, CRC. C. GC.23. Electronic text available here, accessed 2 J July 2019.
} 
increased by more than $4^{\circ} \%$; currently there are 258 million people $355^{\circ}$ of the world's population. Aceording to the UNIICR, in 2017 , there were q $^{\circ}$ million internally displaced persons and another 26 million applicants or holders of international protection. ${ }^{1}$

Since 2006, the issue of migration has been consolidated in the Global Agenda through the first Iligh-Level Dialogue on International Migration and Development of the United Vations General Assembly, by broadening the group of interested countries and inter-agency cooperation mechanisms. In 2013, the Second Iligh-Level Dialogue included migration in the Agenda 2030 for Sustainable Development. ${ }^{5}$ On ig September 2016 , the Member states of the United Vations adopted the Vew York Declaration for Refugees and Migrants, aimed at promoling the establishment of a Global Compact for safe, regular and orderly migration. The Global Compact is framed within objective ro.7 of Agenda 2030 for Sustainable Development, in which Member states committed themselves to cooperate internationally to address all aspects of international migration, including humanitarian, development, human rights and other aspects; to make an important contribution to global governance and improve coordination in international migration; ${ }^{7}$ to present a framework for comprehensive international cooperation on migrants and human mobility; to establish a set of workable commitments, a framework for follow-up and a follow-up system among Member states with respect to international migration. The final text of the Global Compact for Secure, Orderly and Regular Migration was adopted on I3 July 2018; although 153 countries signed it in Marrakesh on $n$ December 2018, ${ }^{8}$ the absence of some of the major receiving states augurs a grim scenario ${ }^{9}$ which, a vear later, is confirmed by the lack of concrete proposals.

The future does not augur a less alarming scenario: in 2050, South America will reach 30 million emigrants and multiply its share of immigrants by $5^{\circ} \%$; in Africa, 78 million are expected." $\triangle$ report by the United Vations Organisation predicts a notable increase in the number of immigrants arriving on European Union territory, reaching ${ }_{5} 6.5$ million, mainly from Africa. In 2017, the U X exposed an alarming reality: Europe, North America and Oceania are net receivers of international migrants; Africa, Asia, Latin America and the Caribbean are net emitters." This explains well the difficulties encountered by multilateralism in finding solutions to regulate the phenomenon of migration and the rights of migrants,

\footnotetext{
1 Report Of The Secretary General, 'Making Migration Mork For NIl', ( $/ 72$ 6/3), 12 december 2or7, Par. 3., electronic text available here, accessed $2 \jmath$ July 2019 .

$5 \quad$ AGRes. 70 / 'Transforming our world: the 2030 Agenda for Sustainable Development', 2 O October 2015 . Electronic text available here, accessed $2 \jmath$ July 2019.

6. AG Res z I'Xew York Declaration for Refugees and Migrants', ıg September 2016. Electronic tevt available here, accessed ${ }_{2}$ Jull 2019 .

7 IO M 'Global Compact for migration'. Electronic text available here, accessed 25 July 2019.

8 Intergubernamental Conference IOM, 'Global Compact For Safe, Orderly And Regular Migration', I3 July 2018. Electronic text available here, accessed 2 July 2019 .

9 K. Daugirdas and J. D. Morteson, "Trump Administration Ends Participation in Global Compact on Migration, Citing Concerns Regarding US Sovereignty', I12, Issue 2, April 2018, Imerican Journal of Inlernalional Lawn (1.JIL) 311-313 at $33^{12}$. |doi: 10.1017 ajil.2018.36|.

1) United Vations Department of Economic and Social Affairs Population Division, 'II orld Population Prospecls: The 2015 Revision, Key Findings and Advance Tables' (ES I P I P.2/2, Vew York, 2015) at 6-7. Electronic text available here, accessed 2 July 2019 .

"Ibidal 9 .
} 
not to mention the problems of approach that some governments show when dealing with a problem mainly of a social nature as if it were national security.' $\mathrm{Nll}$ of this leads to a scenario that we can define as, "struckural anlagonism" in multilateral negotiations.

Included in the large numbers of migration each year, $3^{6}$ million children migrate alone or accompanied.' The often precarious nature of this movement is, according to U VICEF, one of the most vulnerable moments for the safely of children. Currently, according to U NIICR figures, there are so million refugee children, one million more are waiting for a favourable resolution; another seventeen million are internally displaced by various armed conflicts.

This is a decision-making process about which there are no representative statisties, where the child's opinion is hardly considered when families are faced with the decision to migrate. Girls and boys mobilize internationally for a variety of reasons: in search of opportunities, whether for economic or educational considerations; for reunification purposes, in order to regroup with family members who have already migrated; for sudden or progressive changes in the environment that adversely affect their living conditions; for situations arising from organized crime, natural disasters, family abuse or extreme poverty; to be transported in the context of a situation of exploitation, including child trafficking; to flee their country, whether out of well-founded fear of persecution for certain reasons or because their lives, security or freedom have been threatened by widespread violence, foreign aggression, internal conflicts, massive violations of human rights or other circumstances that have seriously disrupted public order.

While children often move with their parents, extended family members or other adults, in 2009 the U X Rapporteur on the Iluman Rights of Migrants warned that an increasing and significant number of children migrate independently and unaccompanied.'‘'

Despite the increase in groups involved in international discussions, migration regulation continues to be inadequately reflected in development frameworks and sectoral policies; neither do they guarantee adequate protection of the human rights of all migrants, nor has public perception of human mobility

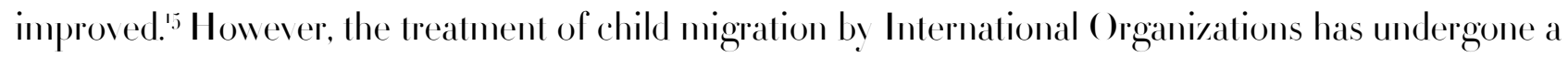
progressive specialization from a generic approach -generated during the great human exoduses- to a permanent, structured and specialized treatment in each of the different realities involved in the term 'childhood'.

12 Mbout Mexico migrant crisis situation. I. Briscoe and A. Matule, 'México: Trump y el lapón migralorio’, ı8, Política Exlerior (2018) 93-99, al 98 .

'3 U NICR, 'Global Trends: Forced displacement in 2018 '. Electronic text available here, accessed 25 July 2019.

's OIICIIR, Promotion and Protection of All Iluman Rights, Civil, Political, Economic, Social and Cultural

Rights, including the Right to Development: Report of U I Rapporteur on the Muman Rights of Migrants, Mr. Jorge Bustamante, U V Doc. A IIRC/ II 7, I/4 May 2009 at par. I9. Electronic text available here, accessed 25 July 2019.

5.5 In 200/, a report from IOM (IOM report, 'The image of migrants in society' MC/IVF/277, I8 noverber 200/ at par. 4. Electronic tevt available here, accessed 2. Juls 20rg) alarms about the much negative public perception about migrants and about it depends on the grade and focus of the information given to societs and encores the states to work for improving the situation. In 2017, an article (T. Raines, M. Goodwin and D. Cutts, 'The Future of Europe Comparing Public and Elite Altitudes', Chatham IIouse: research papers, 2017. Electronic text available here, accessed 25 July 2019 ) explains the existence of a very different perception between the elites and the rest of cilizens (much negative in the last group) about migrations in European Union slate members. 
This development has had an unequal impact on the regulation of states: while some have established specific procedures to manage children crossing their borders, others continue to disregard international obligations imposed by the Convention on the Rights of the Child. In recent years there has been a change in public opinion in receiving countries - traditionally more sensitive to migration when children were involved - towards more intransigent positions that perceive children as the element used by the family to ensure their permanence in the territory of destination; this has given rise to regulations that place them in legal limbo, denying them the enjoyment of rights and even questioning the application of treaties.

For many of them -those who are unacempanied but not exclusively-migration becomes a vital path that exposes them to abuse by traffickers and to detention due to lack of documentation. There is no systematic follow-up or monitoring of these situations. NGOs argue that this is a general but particularly pressing problem in some geographical areas. ${ }^{16}$ For those who move safely, the impact of abandonment of their roots, of their known space has psychological effects as yet little studied.'7

Itaving overeome the diffieulties of the journey, the problems persist at the destination: according to U NICEF, only where there are safe and legal routes can migration offer opportunities for migrant children and the communities they join. ${ }^{18}$ Even so, a refugee child is five times more likely not to attend school than a non-refugee child. Once in school, they are often discriminated, and their difficulties in adapting to the new system complicates their progression at normal rates. Outside the classroom, legal barriers prevent migrant children from enjoying services on an equal fooling with native children, either because of discrimination or because of a lack of an adequate focus on protection measures. ${ }^{19}$ Even those who have arrived in the territory for reasons other than violence suffer such discrimination in access to certain services in addition to needing basic elements for normal development.

In short, it seems that their status as migrants cancels out the special protection that international

16. Save the Children, 'Infancias robadas, informe mundial sobre la infancia 20r7' (London, 3r May 20r7). Electronic text available here, accessed 2 J July 2019 .

${ }^{7}$ Regarding this issue, a review paper stablished in 2008 that "The included studies did not unequivocally confirm that migrant youth are at high risk of developing mental health problems. Both higher and lower levels of problem behavior were found. However, numerous complexities arose that endanger the formulation of further conclusions on the risk of migration for child mental health (...) Finally, generalised conclusions in this research field may not be warranted since particular characteristies of the host countries may also influence the level of mental health problems in immigrant children. More specifically, the ways in which receiving countries select migrants, the attitudes of these countries towards migrants, and international differences in child wellbeing in host countries mav account for the differences. As these factors are not taken into account in most studies, the results of our selected studies are difficult to interpret, as all the above-mentioned factors may blur their results and confound their main findings" (G. Stevens and W. Vollebergh, 'Mental health in migrant children', 49:3.Journal of Child Psvchology and Psvchialry (2008) 276 294 at 279. Electronic tevt available here, accessed 2, July 20rg. |doi: 10.1111 j.1/169-7610.2007.018/8.1); see also, I. Meir, M. Slone and I Lavi., 'Children of illegal migrant workers: Life circumslances and mental health', $34^{(8)}$ Children and Youth Services Review (2012) $5_{5} 4^{6-155^{2}}$. Electronic text available here, accessed 25 July 2019. |doi: 10.1016 j.childyouth.2012.0/4.008|.

is U VICEF: 'Desarraigados: una crisis crecienle para los niños refugiados y migranles' (Xew York, 2016). Electronic levl available here, accessed 25 July 2019.

19. Is an example, the difficulties that have arisen for migrant children with a single parent or refugees for being aligned by children's teams in football competitions in a FIFA state after the modification by the latter regulations on international transfers of children in world regulation football, once the abuse suffered by children were known. 
law and most domestic laws grant to children.

\section{(B) COXCER FOR MIGR IT CIILIDRE I T TIE U ITED \ ITIO \S SISTEM}

Concern for the rights of migrants is not new on the international agenda. Since 1920, the International Labour Organization has coordinated initiatives aimed at promoling fair treatment for migrant workers and their families, the first fruits of which materialized in the 1949 Migrant Workers Convention and the 1975 Vigration Convention. The U X, for its part, protected the right to free movement and to choose the place of residence at an early stage, obtaining normative reflection in the Universal Declaration of I Iuman Rights and in the International Covenant on Civil and Political Rights. In this sense, the rights of migrants have been progressively established in the work agenda of the Organization until its consideration as a particularly vulnerable group. ${ }^{20}$ However, the progress achieved in defining the rights of migrant workers has not followed a uniform trajectory, and it is usually in times of economic prosperity or expansion when the receiving states have shown greater commitment to the introduction of labour improvements ${ }^{21}$ while, in times of crisis or deficit, limitations and setbacks have occurred around those rights surrounding the migrant (family unification, health, schooling, etc.).

In the following vears, international action focused on strengthening the principles underpinning the conditions of access to employment for migrant workers and on finding that the rights of foreigners were not universally protected, because the application of existing international standards and human rights conventions to foreigners was imprecise and unclear. In $198 \overline{5}$, the Economic and Social Council recognized the need to deepen efforts to improve the social situation of migrant workers and their families, through actions at the national, bilateral, regional and international levels. The General Assembly Declaration on the Ituman Rights of Individuals Who are not Vationals of the Country in which They Live called for further protection of those rights. ${ }^{22}$ The Convention on the Rights of the Child does not specifically include the term migrant child; however, it served as a reminder that the status of children as a vulnerable group takes precedence over the specific context in which they find themselves. Its status as the most ratified I luman Rights Treaty in history has made it possible, on the one hand, to break the inv isibility they suffered in the general regulatory framework of migration to meet their specific needs and, on the other, to establish an interpretative authority whose pro-actione positioning has favoured the concretion of its articles in the migratory context.

In 1990, work began on drafting the International Convention on the Protection of the Ituman Rights of All Migrant Workers and Members of Their Families, which entered into force in $2003 .{ }^{23}$ The

20 M. Ferrer, 'La población y el desarrollo desde un enfoque de derechos humanos: inter- secciones, perspectivas y orientaciones para una agenda regional', (LC/L. 2/25-P) 6o (CEP XL, Santiago de Chile, 2005).

${ }_{21}$ M. Abella, 'Los derechos de los migrantes y el interés nacional' in J. Martínez Pizarro and L. Reboiras Finardi, La migración inlernacional y el desarrollo en las Iméricas, LC. L. I632-P (CEP NL, Santiago de Chile, 2001).

22 GI Res. qo/1/43 December ig85.

${ }_{23}$ International Convention on the Protection of the Rights of NII Migrant Workers and Members of Their Families (adopted by G 1 Res. 4.5 158 I8 December 1990, get into force I July 2003). United Vations, Treaty Series, vol. 2220, p. 3. Electronic text available here, accessed 25 July 2019. 
relative lack of concern prior to the Convention can be explained by the small volume of its flows and its limited impact on the economic, political or social stability of the country, but also by a widespread conception that associated migration with the inevitable development of peoples. This does not mean that these people were completely unprotected, because they were covered by other universal instruments; however, the Convention recognized the importance of the welfare of the child and demanded that access to services and social benefits be provided to migrants on an equal footing with nationals. Despite the few ratifications and accessions only jy states, none from the European Union - that it has collected, its adoption and entry into force marked an important step in the recognition of the rights of migrant workers and their families in an irregular legal situation, since prior protection was not given in the particular treaties applicable to this group of persons.

The work of the Convention raised the awareness of the international community by generating a profound discussion on the criminality associated with migration. In 2003, the Global Commission on International Migration identified irregular migration as one of the main sources of vulnerability, especially that of women and children. In this sense, since 200/ the Palermo Protocols opened a space for international collaboration in relation to trafficking in persons and smuggling of migrants with particular attention to child victims.

Once the basic legal corpus for the protection of migrants had been constituted, the International Community has made progress in exploring grey spaces and difficulties in the application of the law through the work of special rapporteurs, treaty monitoring committees, reports from specialized agencies and bodies, and case law: thus, Resolution $2000 / 48$ of the Ituman Rights Council which established the mandate of the Special Rapporteur on the Human Rights of Migrants demanded that its reports consider the rights of migrant children, which culminated in 2009 when it dedicated a specific report to the human rights of migrant children; ${ }^{2 /}$ that same year, the Ituman Rights Council in its Resolution "Iluman Rights of Migrants: Migration and Children Ituman Rights"25 recalled the obligation of states to respect and ensure the protection of the human rights of all children without discrimination under their jurisdiction, and urged them to establish and develop policies and programmes aimed at caring for migrant children based on the best interests of the child, non-discrimination, the right to participation, and the right to survival and development. For its part, the Global Migration Group has directed part of its work to focusing attention on the rights of migrant children and those children affected by migration, including, in 201\%, the Joint Report on "Migration and Youth: Challenges and Opportunities", and it has also established specific positions on children in general spectrum reports. ${ }^{26}$ The previous year, the InterParliamentary Union (IPU) adopted a Resolution to promote the rights of migrant children, especially

24 OIICIIR, supra n.1/.

25 OIICIIR Res. 12 o6 I October 2009 Iluman Rights of Nigrants: migration and rights of the child.

26 Remarkable in this topic are the papers published by the Vigrant W orking Group, specially: MIW G, 'Global Vigralion Group Stocklaking Exercise on Prolection-al-Sea Report and Recommendations' (2015). Electronic text available here, accessed ${ }_{25}$ July 2019. See further: MW G, 'Vigralion, Remillances and Finacial Inclusion: Challenges and Opporlumilies for IVomen's Economic Empowermeni' (2016). Electronic text available here, accessed 25. July 2org; and VIW G, 'Vigration and Youlh: Challenges and Opportunilies' (201/). Electronic text available here, accessed 25 July 2019. 
separated and unaccompanied children, ${ }^{27}$ and the IPU, ILO and OIICIIR published a Handbook for Parliamentarians on Migration, I Iuman Rights and Governance in November 2015.

At the regional level, in 201/4 the Inter-American Court of Iluman Rights issued Advisory Opinion Yo. 2 on the Rights of the Child in the Context of Migration, which had been requested by the Mercosur slates, where it develops human rights standards applicable to unaccompanied migrant children, migrant children and children of migrants ${ }^{28}$, in addition to having developed a copious and interesting jurisprudence on the matter. ${ }^{29}$ For its part, the European Union approved the Plan of Action on Unaccompanied Children (2010-201/), based on prevention, protection and the search for lasting solutions. ${ }^{30}$ Furthermore, scientific doctrine ${ }^{31}$ and civil society have also actively responded by highlighting this reality as well as the need to promote and protect the rights of migrant children and their families. ${ }^{32}$

From the point of view of cultural impact, a good paraneter to measure the growing interest in migrant children is XGR IM in Spanish-speaking scientific and social literature, where it can be observed how since 1992 coinciding with the entry into foree of the Convention on the Rights of the Child there has been a notable and continuous increase in the number of publications mentioning this term. ${ }^{33}$ Migration in international studies and monographs appeared at the end of the last century as one of the most problematic derivalives of globalization. ${ }^{34}$

The Sustainable Development Goals have emphasized another aspect of migration: migration transversality. Beyond trying to highlight the value of migration itself in terms of remittances, student mobility, creation of added value, attracting human capital, amongothers Agenda 2030 has conveved to states the need to address the issue of migration as a starting point for the fulfilment of other objectives.

An example of this transversality can also be seen in the intimate connection between the migratory phenomenon and the rights contained in the Convention on the Rights of the Child. This connection,

${ }_{27}$ Inter-Parliamentary Union Res. 29 / 3 12 September 2013 'El papel de los parlamenlos en la prolección de los derechos de los niños, en parlicular los niños migranles no acompañados, y en la prevención de su explolación en siluaciones de guerra y de conflicto’, ( $/ 129$ 3(c)-R.2). Electronic text available here, accessed $2_{\jmath}$ July 2019 .

28 I ACIIR Consultative opinion n. 2 about Rights of the Children in the context of Migration (OC-21/1/) Electronic text available here, accessed $2_{5}$ July 2019 .

29 I ACIIR cases: Nadege Dorzema vs. República Dominicana (I XCIIR Decision 24 october 20I2). Electronic text available here, accessed 2. July 2019; Pacheco Tineo vs. Eslado plurinacional de Bolivia (I ACIIR Decision 2,j november 2013 ); Viñas Yean y Bosico vs. República Dominicana (I ACIIR Decision 2/1 October 2012). Electronic text available here, accessed ${ }_{2 \jmath}$ Jul 2019.; Niñas Yean y Bosico vs. República Dominicana (I ICIIR Decision 8 September 2ooð). Electronic tevl available here, accessed 2 Julv 2019 .

$3^{\circ}$ European Parliament Com. 2135 June 20ro. Communication from the Commission to the European Parliament and the Council: Action plan on unaccompanied minors (2010 - 201/4).SEC(2010)534. CO M(2010)213 final. Electronic tevt available here, accessed 25 July 2019 .

3י J. Bhabha, Child Migration d I Iuman Rights in a Global Age (Princeton University Press, Jew Jersey, 2016). |doi: 10.239/3 princeton $9780691169101.001 .0001 \mid$.

32 PICU M, 'Iluman Righls of Undocumenled Adolescenls and Youlh’ (PICU M, Bruselas, 201/1); also, C. Musalo, Niñezy Vigración en Centro y Vorle Imérica: Causas, políticas, práclicas y desafíos, (Center for Gender d Refugee Studies, Buenos Aires y San Francisco, 201 .). Electronic text available here, accessed 2. Jul 2019.

33 Igram V iewer. Searching by term "niños migrantes". Results available here, accessed 25 July 2019.

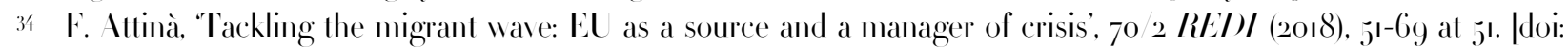
10.17103 redi.70.2.2018.1.02|. Electronic text available here, accessed 2ృ July 2019. 
together with the notable increase in migratory crises, led the Committee on the Rights of the Child to define, in 2015 , the global situation as a human rights crisis that particularly affects unaccompanied children. Finally, the C.MII and the CRC decided to carry out a Joint General Comment on the Ituman Rights of Children in the Context of International Migration in compliance with the mandate of the Ituman Rights Council urging to deepen the interaction and collaboration of the monitoring committees, and the harmonization of their forms of work. ${ }^{35}$ After an open process, in which an open round of consultations with XGOs in the field of children was proposed, an anicus curiae round with International Organizations, Organisms and Agencies, within the CRC, the work was concretized in wo General Observations: firstly, number 22 of the Committee on the Rights of the Child and number 3 of the Committee on the Rights of Migrant Workers on general principles relating to the human rights of children in the context of international migration; and secondly, number 23 of the Committee on the Rights of the Child and number q of the Committee on the Rights of Migrant Workers on the obligations of states concerning the human rights of children in the context of international migration in countries of origin, transit, destination and return.

The inseparable nature of both is evident. In the Committee's view, the implications of migration for children exceeded the formal limits set for a general comment - a maximum of so,7oo words is recommended - so it decided to devole lwo.

Following the Committee's own criterion which expressly indicates that the wo should be read and considered together we will refer to both as the General Comment on the rights of migrant children.

\section{(C) TIIE GE NER NL COMIENTON TIIE RIGITS OF MIGRINT CIILDREN}

As for the so-called conventional mechanisms, each United Xations human rights treaty has a body whose main purpose is to supervise the compliance of ratifying states with the specific provisions of the treaty.

The General Comments seek to clarify the content and scope of treaty obligations. They contribute to the compliance monitoring function by addressing highly relevant issues of treaty interpretation, including a preventive function - in light of shortcomings highlighted by a large number of reports and guidance, as well as an assessment of good practice implementation. ${ }^{36}$ In general, the Committee on the Rights of the Child constitutes an "authorized interpreter" although the terms included in the General Comments are recommendations for adequate implementation (they help national authorities to identify deficiencies, design policies and adopt measures to give effect to the rights contained in that instrument) and therefore do not necessarily imply obligations specifically accepted in the ratified Convention; therefore, their non-application may have negative consequences in the assessment of the periodic reports that states must present, but does not imply -directly- incurring international responsibility. The letter of the General Observations itself shows the degree of obligation that states must meet by distinguishing,

\footnotetext{
35 OIICIIR Res. 68/268 9 April 201/p. Electronic text available here, accessed 25 July 2019.

36 The Iluman Rights Committee has ruled on the purpose of the General Observations (CCPR/ C/21 Rev.ı); the General Assembly, about its nature and purpose ( $\mathrm{N}_{4} \mathrm{O}\left(\mathrm{N}_{3} 6 / 4^{\mathrm{O}}\right)$.
} 
from the lowest to the highest level of obligation, between "should" and "must", which includes two levels of obligatory intensity -"shall" and "must"- as a matter of priority.

Thus, the joint elaboration of the General Comment on children's rights in a context of international migration by the Committee on the Rights of the Child and the Committee on the Rights of Migrant Workers has an integrative effect: on the one hand, it establishes an interpretative definition that applies to all Member states of the European Union as a party to the Convention on the Rights of the Child and, on the other hand, it avoids harmful effects that could occur - in relation to migrant children - due to their failure to ratify the Convention on the Rights of Migrant Workers and their Families. A joint reading of Observations 22 and 23 shows the following five main axes:

- Empower migrant children as holders of human rights by enervating the protection afforded by human rights treaties through their concretion in situations of risk and violation of rights in migrant children.

- Promote a comprehensive migration management system concerning states of origin, transit, destination and return that improves the conditions of migrant children and the application of the principle of national treatment and non-discrimination in the enjoyment of rights.

- Eliminate those approaches that result in migrants taking precedence over, and even cancelling out, their status as children; as well as those practices that tend to limit the enjoyment of rights because of the migrant status of their parents.

- Remember that states have the right to determine the conditions and flows of persons across their borders, but that excessively restrictive regulation may indirectly lead to situations of human rights violations and the promotion of criminal activities around the migratory phenomenon; also, that irregular access to foreign territory by a person may be subject to sanctions but never of a criminal nature and, consequently, may not imply the limitation of the human rights of migrants in an irregular siluation.

- The conviction that excessively restrictive regulations on access to territory or repressive regulations on irregular stay can lead to situations of violation of human rights or lack of access to basic services for fear of being deported. For this reason, the Observation seems to advocate a sort of separation in the Administration that prevents the communication of data between those units dedicated to the protection of children and the provision of basic services (health, education, social assistance, ete.) and the units destined to regulate and execute migration policy. The Comment calls for the establishment of a "firewall" and the prohibition of the exchange and use for immigration enforcement purposes of personal data collected for other purposes, such as protection, reparation, civil registration and access to services. This is necessary to uphold the principles of data protection and to protect the rights of the child in accordance with the Convention on the Rights of the Child.

The members of both Committees insist on highlighting the character of children as a key element in the duty of states to respect, protect and fulfil their rights in the context of international migration, irrespective of their residence status or that of their parents or guardians. Responsibility for children connected to jurisdiction is absolute and covers the whole territory and even international waters, as well as any space 
restricted or reserved for the management of immigration.

The Committees urge that the migrant child be made visible as a reality that states must deal with in the framework of their policies and whose impact on these must be considered at the time of their evaluation which includes the public dissemination of data and results and the design of new policies. Such policies should be comprehensive, inter-institutional, connected between welfare authorities and other competent bodies (health, education, ete.) and inter-territorial; they should be endowed with enough resources, including budgetary resources and implemented by officials with continuous and periodic training on the rights of children, migrants and refugees and on statelessness, including intersectional discrimination. ${ }^{37}$

\section{(1) General Principles}

Comment to 22 focuses on establishing compliance with five general principles as the main element in the protection of the rights of migrant children:

- The prohibition of discrimination, which must operate regardless of the cause of the transfer (economic, seeking asylum or refuge, etc.). The Comment considers non-discrimination as the central axis on which to build the set of state policies and limits the discretion of the Governor to establish exceptions by indicating that these must be supported by international standards and norms, the best interests of the child and be proportional. The Committee points out the main grounds of discrimination but requires particular attention to those caused by gender identity. ${ }^{8}$ As if it were a quality process, the Convention starts from the idea that the existence of situations of discrimination is connatural to the environment and that the duty of states cannot be limited to establishing legal parameters that prohibit it, but must actively act to reflect on and combat it. ${ }^{39}$

- General Comment No. 22 reflects the principle of the paramount consideration of the best interests of the child set out in General Comment Vo. $1_{1}{ }^{0}$ and its concreteness in the context of international migration. The best interests of the child relate both to the child's individual sphere and to his or her relational orbit with regard to the expulsion of his or her parents or guardians. Thus, "best interests" determination" as a structured and strictly guaranteed process designed to determine the best interests of the child on the basis of the best interests' assessment is configured as a complex process including the development of individual sustainable reintegration plans that must be addressed at each stage of the migration process and continued in the state of destination until such time as migrant

\footnotetext{
37 Para. 11-22 General Comment Vo. 22 (2017) of the Committee on the Rights of the Child on the general principles regarding the human rights of the international migration, CRC C GC/22, Electronic text available here, accessed 25 July 2019 .

$3^{8} \quad$ Para. 2/GC no.22 (2017). Electronic text available here, accessed 2.j Julv 2019.

39 Ibidem at para. 26 . Electronic text available here, accessed 25 Juls 2019 .

10 General comment \o. 1/4 (2013) on the right of the child to have his or her best interests taken as a primary consideration (art. 3, para. I). Adopted by the Committee on the Rights of the Child at its sivty-second session (1/ January - I February 2013 ). CRC C GC/1/. Electronic text available here, accessed 2ృ July 2019.
} 
status ceases to be a factor in the child's life.' Other considerations, such as those relating to the overall control of migration, cannot prevail over considerations based on best interests.

- The third principle on which the General Comment rests the construction of policies relating to migrant children is their right to be heard, to express their views and to their participation developed in General Comment No. 12. . $^{2}$ The Committees consider that states should establish procedures that allow children to express their views - independent of those of their parents or family - as parties to migration and asylum processes, and that their views be considered. As part of the process, their interests should be protected by a qualified representative who is also familiar with the child's ethnic, religious and cultural characteristies. Such representation is not a substitute for the child's right to be informed of his or her rights, services and resources available to him or her in his or her own language. For their part, states must remove all obstacles that prevent children from expressing their views and foster a context in which civil society organizations emerge for this purpose. i3 $^{3}$

- The fourth principle is the duty to respect the right to life, survival and development of every child. The Commitlee views the migration process as a period where the child's vulnerability is considerably undermined and recognizes the difficulty of establishing regular and safe channels for child migration. However, it requires the adoption of measures, including access to judicial and non-judicial remedies, aimed at preventing and reducing the risks associated with migration in states of origin, transit and destination. The Committee is concerned that the effects of migration processes, including migrant status itself, may directly or indirectly affect children's right to life, survival and development irrespective of their status or that of their parents in the state of destination. 'í

- Finally, the Committee recalls the responsibility of states in receiving migrants in their states and their duty to respect non-refoulement obligations under international refugee law: thus, it recalls the prohibition of expelling, individually or collectively, children from their jurisdiction when there is a risk of irreparable harm upon return, such as persecution, torture, serious human rights violations or other irreparable harm. The Comment recalls the full validity of international agreements on this issue and the existence of an unambiguous interpretation of the principle of non-refoulement without an effective process with all due process guarantees and the right of access to justice.

\section{(2) On age determination}

A key issue for the implementation of the state obligation in relation to migrant children is the determination of age at the time of entry. Failure to do so not only violates the rights of the child when he or she is classified as adult and is therefore deprived of the protection system to which he or she should be

\footnotetext{
亿 Para. 31-33 GC. 17.22 (2017). Electronic text available here, accessed 25 July 2019.

$1^{2}$ General Comment Vo.12 (2009) The right of the child to be heard. Adopted by the Committee on the Rights of the Child at its Fifty-first session (Geneva, 2 j May 2009 -12 June 2009). CRC. C/ GC/12. Electronic tevt available here, accessed 2 j July 2019 .

13. Para. $3^{8-39}$ GC Vo. 22 (2017). Electronic text available here, accessed 2 Jull 2019.

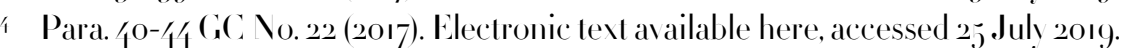

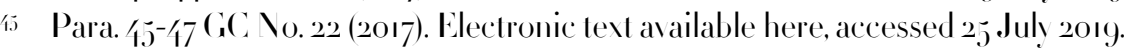


entitled; but also when adults are erroneously considered minors, thereby harming the group of children covered by the system who are forced to live with that person. This situation wreaks havoc on the proper development of children and as has already been stated by some authorities also on the functioning of public services. ${ }^{40}$

It is not always easy for migrant children to provide the required documentation. In Observation No. 23 , the Committee recalls that physical tests to determine the age of a migrant child should be carried out only if it is not possible to make decisions on the basis of documentary evidence ${ }^{\text {in }}$ and, always by paediatricians or other professionals through a global assessment of their development and thus abandon other more intrusive methods $;^{8}$ on the other hand, there is scientific literature that sustains the fallibility of such methods. ${ }^{19}$ The Committee points out the obligation to consider unless there is proof to the contrary documents presented by children to attest to their age as valid. It is also concerned about migrant children between the ages of $\square_{5}$ and 8 as they often receive much lower levels of protection and are sometimes regarded as adults or maintain ambiguous migration status, recalling that states must take adequate follow-up, support and transition measures for children approaching 18 years of age; ${ }^{5^{\circ}}$ the Committee encourages states to adopt protection and support measures even after that age to assist them in the transition to coming of age.

(3) With regard to deprivation of liberty

The Comment recalls that, according to the Convention on the Rights of the Child and the International Convention on the Protection of the Rights of All Migrant Workers, the detention of any child on the basis of the residence status of his or her parents constitutes a violation of human rights, and therefore, the detention of any kind of child as an immigrant should be prohibited by law. Such consideration extends to any situation in which a child is deprived of liberty for reasons related to his or her migratory status or that

$4^{6}$ Spanish Prosecutor General's Office. Menores extranjeros no acompañados: valoración de los documentos de identidad extranjeros en los expedientes de determinación de la edad, 2orz |request: 22 May 2org|. Electronic text available here, accessed 2 J.Julv 2019 .

it However, as T. Smith and L. Brownlees Laura show, despite the subsidiarity of biometric and forensic methods, it is legally practical evidence that medical tests are not used as a last resort. (T. Smith and L. Brownlees, 'Age assessment practices: a lileralure review de annolaled bibliografphy', Discussion Paper (U VICEF. Jew York, 20ut). Electronic text available here, accessed 2 July 2019 .

is The Committee does not expressly mention them but by "physical evidence" it refers to the four types of exams - based on the four Daubert criteria to judicially validate a medical test - to which migrant children are subjected: a) the physical examination based on the Tanner scale; b) the radiographic examination of the carpus of the left hand (following some of the following scales: the Greulich and Pyle atlas, the Tanner-W hitehouse measurement or, the combination of both-FELS-); c) the radiographic examination of the denture (based on the methods of Logan and Kronfeld, Schour and Massler or Demirjial) and finally, d) the radiographic examination or computed tomography of the proximal clavicle limb (based on the Schmeling method).

19 T. García, 'El procedimiento para la determinación de la edad de los extranjeros no acompañados. Bases para un nuevo modelo' (LL,M Thesis on file Universidad Pontificia de Comillas, 2017). Electronic text available here, accessed 25.July 2019.

$5^{\circ}$ Para 3 Joint General Comment Vo. 4 (2017) of the Committee on the Protection of the Rights of NII Migrant WVorkers and Members of Their Families and General Comment Vo. 23 (2017) of the Committee on the Rights of the Child on State obligations regarding the human rights of child, CRC C GC 23 . Electronic text available here, accessed 25 July 2019. 
of his or her parents, regardless of the name or reason given for the measure of deprivation of liberty of the child, or the name of the facility or the place in which the child is deprived of liberty. The Committee does not deny the legitimate interest of states in controlling and regulating migration at their borders, but considers that irregular entry and stay is not a crime against persons, property or national security and therefore the detention of children and their families as immigrants should be prohibited by law ${ }^{51}$ and its abolition guaranteed in theors and practice..$^{2}$

Children may not be criminalized or subjected to punitive measures, or deprived of liberty in proceedings relating to their migratory status or because they are alone; in this regard, it considers that the adoption of such a measure is excessively disproportionate, even amounting to cruel, inhuman or degrading treatment of migrant children. The Committee urges states to adopt measures that allow children to remain with their family members without being in custody, as the motivation to keep the family together and the contact with the family is insufficient to justify the deprivation of a child's liberty.

(4) With regard to access to justice

The Observation also emphasizes the right of children to have access to the bodies and courts that must decide on situations affecting them, as well as to the guarantees and remedies therein. It also recalls the obligation that such decisions be taken in the best interests of the child by proposing concrete measures to be taken in the case of migrant children during the process. ${ }^{53}$

\section{(5) Right to an identity}

The Committees are also concerned about the fulfilment of the right to a name, an identity and a nationality recognized in both Conventions. They affirm the existence of regulations that dissuade migrants from registering their children for fear of being asked about the regularity of their migration status, and urge states to prohibit the exchange of data between registration and immigration officials and recall that unregistered or stateless children are equally entitled to health, education, protection and other social rights. They also call for flexibility in international cooperation when forged documents had been obtained to facilitate the migration or registration of a child, and the child requests that the authentic documents be handed to him or her, without this entailing the application of punitive measures against him or her. They recall the duty of states to cooperate to prevent statelessness and the existence of a forum necessilatis involving the granting of nationality at birth or immediately thereafter if; failing that, the person becomes stateless; They proposes the repeal of laws that prevent migrant women — especially those under the age of 18 - from contracting marriage from retaining, changing and transmitling their nationality to their children.

\footnotetext{
Ibidem at para. I2. Electronic text available here, accessed $2 j$ Julv 2019.

$5^{2} \quad$ Ibidem at para. $5^{-10}$. Electronic tevt available here, accessed 25 Juls 2019 .

33 Ibidem at para. 12. Electronic text available here, accessed 25 July 2019.
} 


\section{(6) The right to family life}

The right to family life is especially complex for migrant children, so the Comment, after reaffirming its validity in conventional international law of universal and regional scope, addresses it in two different moments:

- First, when there is separation of parents or guardians, it being understood that while the right to family unity may interfere with the freedom of states to regulate the entry or stay of aliens in their territory, an expulsion measure must be interpreted negatively because of the impact it will have on a child to be deprived of his or her family member; such a measure may constitute a violation of the right to family unity. The Committees also denounce the existence of numerous cases of separation of parents and children for reasons of poverty and that poverty, in order to provide alternative care or to prevent their social reintegration, can never be applied as the sole reason for separating them from their parents; in this case, support measures must be applied by the state to alleviate this situation of poverty. ${ }^{51}$

- Secondly, with regard to the right to family reunification and, in this regard, the General Comment recalls that applications must be dealt with proaclively, humanely and expeditiously and that, if rejected, the child must be informed of the reasons for the decision and of the remedies available to oppose it. In cases where the reunification of the child with his or her family in the country of origin, transit or destination must be determined, the decision will be addressed through a comprehensive analysis that includes his or her right to be heard and a plan for insertion into the new sustainable society. In the case of unaccompanied minors, the Comment establishes that reunification can only take place in a country that is safe for the child. In cases of family reunification, the Committee recalls the primary responsibility of states of destination, but also the duty of states of origin and transit to be flexible and agile insofar as it involves them. In this sense, it seems logical that the Observation does not offer a taxed solution for these cases but that the final destination, when approached from the perspective of the best interests of the child, is subordinated to the specific characteristies of the case.5.5

(7) State's right to control the entry and stay of foreigners

With regard to the state's right to control the entry and stay of foreigners in its territory, the Committees warn of the existence of a directly proportional relationship between excessively restrictive and expeditious migration policies with irregular migrants and the emergence of forms of abuse and exploitation of children, including abduction, trafficking in children or their use in begging or child labour. The Comment recalls the responsibility of states to take appropriate measures to prevent such activities during their stay in their territory and especially during transfer to the place of destination. The text recognises the special vulnerability of girls held in consultation rounds with international organisations and YGOs to trafficking, especially for sexual exploitation; this attention to diversity should be extended

\footnotetext{
34 Ibidem at para. 28-3. Electronic text available here, accessed 2.j Juls.

.5. Ibidem at para. $3^{2-3} 8$. Electronic text available here, accessed 25 Jul. 2019.
} 
to lesbian, gay, bisexual, transgender or intersex children, as well as those who may have a disability. Paradoxically, in the face of the separation between units of the state, the text also indicates the need to apply a global protection of children -specially girls- victims of sexual exploitation through better coordination between the different institutions of the state and with the participation of professionals from different areas. In relation to children who are victims of sale, trafficking or exploitation, the Comment proposes to orient the applicable law towards the granting of the most protective status among those available..$^{-6}$

\section{(8) Standard of Living}

The Comment recalls the obligation of states to ensure that migrant children enjoy a standard of living adequate for their physical, mental, spiritual and moral development, urging them to prepare detailed guidelines on standards of reception services, ensuring adequate space and privacy for children and their families. In relation to temporary accommodation, it should consider gender separation, be suitable for persons with disabilities, the particularities of motherhood and should not unnecessarily restrict the daily movements of children by effectively imposing restrictions on their movement. It also provides that states should promote their access to housing. The Comment also recalls the special and often urgent mental health needs of migrant children. ${ }^{37}$ It promotes a holistic approach to the right to health and recalls that restrictions imposed on the right to health of adult migrants because of their nationality or migration status could also affect the right to health, life and development. The right to education is also mentioned in the General Comment - in reference to both primary education and vocational training- which must be provided on an equal footing with nationals of the country in which they live and ensuring the elimination of any grounds of discrimination; targeted and alternative education is also promoted where necessary and the possibility of participating fully in examinations that enable them to obtain recognized training. The document affects the fear of migrants to be deported or sanctioned when using social services, therefore, the Comment promotes that providers are not required to present any document; as well as the separation in the Administration between those units dedicated to provide services and those dedicated to suppress irregular immigration..$^{-8}$

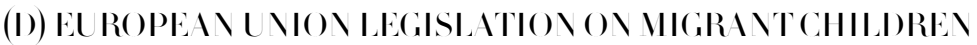

\section{THE LIGHT OF THEGENER ULCOMVIE\T}

In 2016, 1,259,26 j people applied for international protection in Europe; in 2017, 650,000 more did. According to data from the International Organization for Migration (IOM), more than ,ooo people lost

$5^{66}$ Ibidem at para. 39. Electronic text available here, accessed 25 Julv 2019.

57 Some NGOs have alread warned of mental health problems in children associated with migration as an invisible crisis. Muman Rights Watch, 'EU Greece: Asylum Seekers' Silent Menlal Ilealth Crisis' (IIRII, Jew York, 2017) at Some \GOs have alread warned of mental health problems in children associated with migration as an invisible crisis. Electronic text available here, accessed ${ }_{25}$.Jul 2019 .

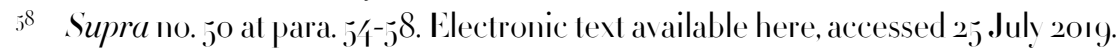


their lives trying to reach European coasts from Morocco, Libya, Turkey or Egypt. In addition, there are an estimated 353,348 irregular entries into European Union territory via unsafe roules.

The European Union has repeatedly expressed, in recent years, the complexity of the situation of migrant children in its territory: assuming U VICEF data, it recognizes that there are 5 . 4 million migrant children, which means $7.4^{\circ} \%$ of all migrants in the territory of the Union and that one in four asylum seekers in a European Union country is a child; of these, $9^{6,000}$ are unaccompanied children. According to Eurostat, during 2016 the number of asylum-seeking children in some of the states of the Union reached 386,$435 ; 173,45^{\circ}$ of whom arrived in Greece by sea; 181,436 went to Italy and 8,162 to Spain. In 2017 , the figure fell to $188,93^{\circ} .{ }^{39}$

(1) Original European Union Law

Article $3(2)$ of the TEU states that 'the Union shall offer its citizens an area of freedom, security and justice without internal frontiers, in which the free movement of persons is ensured in conjunction with appropriate measures relating to external border controls, asylum, immigration and the prevention and combating of crime'. The policies to develop this area of freedom, security and justice have followed three multiannual programmes: the Tampere Programme (1999-2004), the Hague Programme (2005-2009) and the Stockholm Programme (2010-201/).

Article $3: 3$ of the TEU expressly establishes the Union's obligation to promote the protection of the rights of the child. For its part, Article 2/4 of the Charter of Fundamental Rights recognises children as independent and autonomous holders of rights and that the best interests of the child should be considered paramount for public authorities and private entities. All Member states are party to the European Convention on Iluman Rights and Fundamental Freedoms and to the Conventions signed within the framework of the Council of Europe.

All Member states have ratified the Convention on the Rights of the Child and, with a few exceptions, ${ }^{60}$ all are parties to the Additional Protocols. On the contrary, neither the Member states, nor the European Union itself, participated in the negotiations that led to the Convention on the Rights of Migrant Workers and their Families; ${ }^{61}$ nor have they ratified it.

The European Union has not foreseen a specific definition of "child"; the paradox arises that in those European policies complementary to the states (education, health, migration, etc.) it delegates the interpretation to the internal law of each state which normally implies the application of Article a of the Convention on the Rights of the Child which considers children only to those under is years of age ,

59 European Commission, 'Compilation of dala, siluation and media reporls on children in migration Parl I - dala and

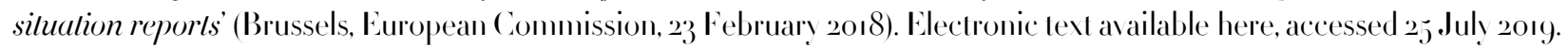

6o The Optional Protocol to the Convention on the Rights of the Child on the involvement of children in armed conflict has been ratified by all EU member states except Estonia. The Optional Protocol on the Sale of Children, Child Prostitution and Child Pornography has been ratified by all EU member states except the Czech Republic, Finland, Ireland, Luxembourg and Malta.

6. Supra no. 23. It got into force s July 2003, just fifty-lwo states have ratified the Convention. Electronic text available here, accessed $2 \leftrightharpoons$ July 2019 . 
whereas when it comes to European freedoms such as the freedom of movement of citizens of the Union the Commission extends this consideration to those under 2 y vears of age or under the care of their parents. ${ }^{62}$

Furthermore, the Union has legislative powers in the field of immigration and asylum from third countries. In the case of migrant children, the cases covered by Community law refer to situations of long duration for reasons of work, asy lum and subsidiary protection, as well as the situation of immigrants in an irregular situation. In addition to the abovementioned Article 2/4 of the Charter of Fundamental Rights of the Union, Articles 8 and 19 of the Charter regulate the right to asylum and protection in the event of refoulment, expulsion and extradition. ${ }^{63}$

Therefore, the normative framework for the protection of migrant children on Union territory pivots on the interaction between the Charter of Fundamental Rights, the European Convention on Ituman Rights and the Convention on the Rights of the Child; however, until the adoption of the Charter, the European legislator refrained from assigning any concrete value to the Convention on the Rights of the Child in matters of migration; however, since then, references in Union law and judgments have been constant. 6 ,

(2) Secondary european union legislation

\section{(a) Legal framework of the fundamenlal rights of migrant children in the European I nion}

In Europe, several of the fundamental rights recognized by the Convention on the Rights of the Child fall within the competence of the Member states, but they do fall within the competence of the European Union's secondary legislation to guarantee that children can enjoy them without discrimination because of their migrant status. In many respects, current migrants from third countries benefit from the body of rules and judicial decisions rooted in the EC.J aimed at preventing discrimination between European citizens displaced within the territory of the Union. On the other hand, its current real effectiveness arises to a large extent from its concurrence, in the territory of the Member states, with the Charter of Fundamental Rights and the regulations arising within the Council of Europe.

Vigrant children from third countries enjoy access to state-funded education under similar conditions to nationals, but are excluded from complementary assistance. In the case of access to education for children seeking international protection, it must be similar to that of nationals, but not identical, which means that, in many Member states, they receive education in migrant detention centres where, in addition, their normal beginning and development is disrupted by the conditions deriving from the asylum system. Nevertheless, the European Union has undermined the protection of migrants by

6.2 Directive 200/48 EC of the European Parliament and of the Council of 29 April 200 / on the right of citizens of the Union and their family members to move and reside freel within the territory of the Member States amending Regulation

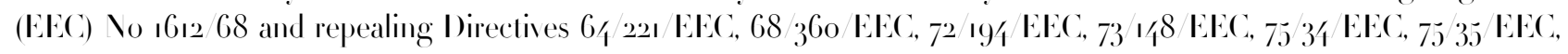
$9^{\circ} 3_{6}^{6}$ EEC, $90 / 3_{5}^{6}$ EEC and 9396 EEC. Electronic text available here, accessed $2_{5}$ July 2019.

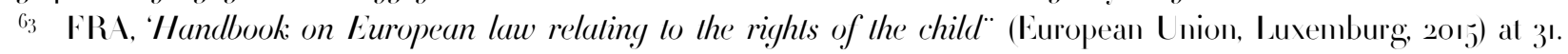
Electronic text available here, accessed 2 July 2019.

6ri Ibidem. 
obliging states to recognize and transfer qualifications obtained in their country of origin or countries in transit even in the absence of documentarv evidence. ${ }^{6,5}$

With respect to the Right to Itealth, migrant children from third states have access to health in the territory of the European Union in terms similar to those enjoyed by nationals, but subject to limitations except when they are in a situation of special vulnerability or there is a risk to their lives. The European Social Charter, various pronouncements of the European Committee of Social Affairs ${ }^{66}$ are the essential support for children's rights to social benefits and health services regardless of their migratory status.

Only an overall view and not one focused exclusively on European Union legislation - can ensure their relative conformity with the General Comment on the rights of migrant children.

\section{(b) The Dublin Syslem and ils impact on migrant children}

In 2006, the Commission laid a foundation for promoting and protecting the rights of the child in its internal and external policies through its Communication "Towards an EU Strategy on the Rights of the Child". In 2007, the Communication "An EU Agenda for Children's Rights" was adopted, which affirmed the need to implement the "child rights perspective" in all EU measures affecting children, recognised the absence of reliable aggregate data on children - particularly unaccompanied children , identified those who had been trafficked and sexually abused as particularly vulnerable, and recalled the mandate of the Charter of Fundamental Rights to the Commission on its duty to verify respect for recognised fundamental rights. ${ }^{{ }^{7}}$

In 2010, the European Parliament adopted the Communication from the Commission to the European Parliament and the Council on the Action Plan for Unaccompanied Children (2010-201/). The Plan sought to establish specific reception measures and procedural guarantees for children, applicable from the moment the child is located until a durable solution is found. At that time, the concern was to ensure adequate representation of the child in the proceedings, actions were proposed to address the failure of care provided to unaccompanied asylum-seeking children, as well as the adoption of measures to prevent the disappearance of unaccompanied children in the care of the public authorities of the states Parties. 68

The European Convention for the Protection of Ituman Rights and Fundamental Freedoms (ECIIR) does not explicitly protect the right to asylum, but the jurisprudence of the European Court of

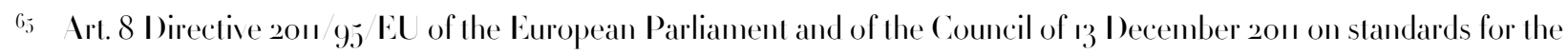
qualification of third-country nationals or stateless persons as beneficiaries of international protection, for a uniform status for refugees or for persons eligible for subsidiary protection, and for the content of the protection granted. L 337 9. Electronic text available here, accessed 2, Jull 2019.

66 ECSR Cases: ECSR Decision Defence for Children International vs. Belgium, case no 69 2011,23 October 2012. Electronic text available here, accessed 2 July 2019. See also ECSR Decision International Federation of Iluman Rights Leagues us. France, case no 1/4 2003, 8 September 200/4, at 35 37. Electronic text available here, accessed 25 July 2019.

$6_{7}$ Commission Communication of / July 2006 - Towards an EU strategy on the rights of the child. COM(2006) $3^{67}$ final. Electronic text available here, accessed 25 Julv 2019 .

68 European Parliament Com. 213.5 June 2010 Communication from the Commission to the European Parliament and the Council: Action plan on unaccompanied minors (2010 - 2014). SEC (2010)534.COM (2010)213 final. Electronic text available here, accessed 2 July 2019 .
} 
Human Rights ${ }^{69}$ points to indirect protection for asylum seekers and refugees, imposing limitations on states' sovereign right to deny access to their territory..$^{\circ 0}$ These limits are determined in the application of Articles 2 and 3 of the ECIIR in relation to the expulsion or extradition of a foreign person to a third country or between countries of the European Union.

Article 21 of Directive 201333 EU of the European Parliament and of the Council of 26 June 2013 laving down standards for the reception of applicants for international protection contained a taxable list of vulnerable persons among applicants for international protection, whose special situation must be assessed when determining the material conditions of reception by Member states.

This list includes, among others, "minors, unaccompanied minors, pregnant women, single parents with minor children, victims of trafficking in human beings". Articles 23, 2/4 and 2ృ specifically mention children and victims of torture and violence, implicitly placing them in a hierarchically superior position in comparison with other particularly vulnerable groups of applicants. ${ }^{71}$

The Common European Asylum System (CE AS), the aim of which is to ensure criteria common to all Member states and to ensure a minimum of benefits available to applicants and beneficiaries of international protection, has already introduced improvements in the second version of the Dublin System with regard to migrant children, such as: a) a revision of the concept of family members with priority consideration of the best interests of the child in legislative developments and measures to be implemented by countries; b) the incorporation of measures for the protection of unaccompanied minors through the adoption of formulas for representation and guardianship; (b) the incorporation of measures for the protection of unaccompanied minors through the adoption of formulas for representation and guardianship; (c) the obligation of states to guarantee the schooling of children and access to the health system from the moment they submitted their application; (d) it gave preference to procedures for family reunification when there are dependent minors; and, finally, (e) it required supervision by a legal representative of the child of the procedure in taking a decision on their application. ${ }^{7^{2}}$

Despite these improvements, on 26 August 2013, in the report on the Plan for Unaccompanied Minors, the Parliament found it "deplorable that the protection of minors is "significantly and persistently underfunded" compared to other areas of humanitarian action" and urged the Commission to include unaccompanied children in the European Asylum and Immigration Fund and, among other measures, considered it essential to introduce a coordinated method of data management at EU level by

\footnotetext{
69. Among others, Mubilanzila Maveka v. Belgium ECIIR Vo. $13178 / 0312$ October 2006 regarding to a five vears old girl unaccompanied who was jailed with unknown women. Electronic text available here, accessed 25 July 2019 ; Khlaifia and others is. Italy ECIIR \o. I6/83 20126 December 2016 . Electronic text available here, accessed 25 Jul 2019.

$7^{\circ}$ ECIIR, Asylum Court talks Iluman Rights Education for Legal Professionals”, Council of Europe, 2or6. Electronic text available here, accessed $2 \jmath$ July 2019 .

7 European Directive 201333 EU of the European Parliament and of the Council. Laving down standards for the

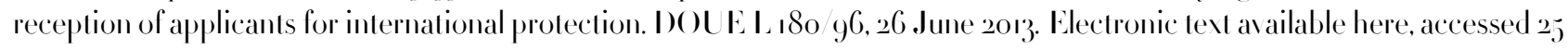
July 2019 .

$7^{2}$ Art. 6 Council Regulation (EC) No 3432003 of 18 February 2003 establishing the criteria and mechanisms for determining the Member State responsible for examining an asy lum application lodged in one of the Member States by a third-

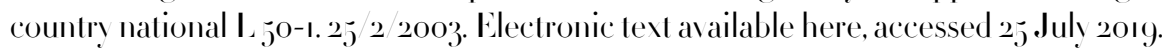


strengthening the role of Frontex and Europol and by involving the European Migration Vetwork. ${ }^{73}$

According to U NIICR, the biggest problem identified in the implementation of the Dublin II Regulation was the absence of common protection criteria in all Member states that are part of the system and divergences in national practices in informing applicants or assessing the vulnerability of individuals and their needs. For its part, the Grand Chamber of the EC.J recognised in a judgment on Joined Cases C佂 10 and $\mathrm{C}-493$ to that the fundamental rights of applicants for international protection were not guaranteed in all Member states, which prevented the automatic application of the Regulation.71

The third version of the Dublin Regulation ${ }^{75}$ included improvements with respect to the previous system for migrant children, including its material extension to stateless children; the implementation of the principle of the best interests of the child in relation to the possibilities of family grouping, their wellbeing and their protection in cases of particular vulnerability; and the strengthening of family reunification in the hierarchy of criteria (Articles 7:3, 9 and so) for the granting of international protection; provided for the creation of a standard form for the exchange of information on the family of unaccompanied minors; set up a family procedure in the event that several members of a family or unmarried minor siblings submit simultaneously, or at close dates, an application in the same Member state, bringing logether the responsibility for examining the application of all of them to a single state; required a personal interview of the applicant ${ }^{7^{6}}$ and the right to lodge a judicial appeal against the transfer decision with the right to free legal assistance and, where appropriate, the assistance of an interpreter ${ }^{77}$; finally, it requires applicants to be informed of the application of the Regulation, of the procedure for transfer of responsibility and of the transfer to another state, in writing and in their own language. ${ }^{8}$

Dublin III was thus shaped by the above-mentioned Regulation, by Regulation (EU) 603 2013 on the Eurodac sy stem, ${ }^{79}$ by Directive $2013 / 3^{2}$ EU of the European Parliament and of the Council of 26 June 2013

73. Motion for a European Parliament resolution on the situation of unaccompanied minors in the EU. $2012 / 2263$ (IVI). 26 August 2013 . Electronic text available here, accessed 2 July 2019 .

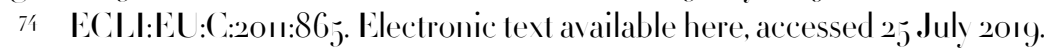

75 Regulation (EU) $\mathrm{V}_{0} 60_{1} 2013$ of the European Parliament and of the Council of 26 June 2013 establishing the criteria and mechanisms for determining the Member State responsible for examining an application for international protection lodged in one of the Member States by a third-country national or a stateless person. Li8o 3r. DOU E 26.3.2013. Electronic text available here, accessed $2 \subsetneq$ July 2019 .

$7^{6}$ Ibidem at Art.. . Electronic text available here, accessed $2_{\jmath}$ July 2019.

77 Ibidem at Art. 27. Electronic tevt available here, accessed 25 July 2019.

$7^{8}$ Ibidem at Art. 4. Electronic text available here, accessed 25 July 2019.

79 Regulation (EU) no. 6032013 of the European Parliament and of the Council on the establishment of EU ROD AC for the comparison of fingerprints for the effective application of regulation (EU) no. 6o/ 2013 establishing the criteria and mechanisms for determining the member state responsible for examining an application for international protection lodged in one of the member states by a third-country national or a stateless person and on requests for the comparison with EU ROD AC data by member states' law enforcement authorities and Europol for law enforcement purposes, and amending Regulation (EU) no. 1077201 establishing a European agency for the operational management of large-scale it systems in the area of freedom, security and justice. L 180/. 29 June 2013 . Electronic text available here, accessed 25 Julv 20rg. The Database, common to all Member States and Torway, Switzerland and Iceland, serves to identify asvlum seekers and irregular migrants crossing the border; With this, the authorities will determine whether they have already applied for asylum in another Member State. 
on common procedures for granting and withdrawing international protection ("Procedures Directive") ${ }^{80}$ and by Directive 201333 EU of the European Parliament and of the Council of 26 June 2013 laving down standards for the reception of applicants for international protection ("Reception Directive"). ${ }^{8}$ To complete this reform, Regulation ${ }_{18} 8 / 201 / 4$ amending implementing Regulation (EC) $\mathrm{V}_{0} 5_{5} 60 / 2003$ was also adopted in $2014^{8}{ }^{82}$

In 2016, the European Commission published a report —echoing an earlier one published by the House of Lords_ ${ }^{8}$ in which it held that the conditions of reception of unaccompanied minors in several Member states amounted to systematic detention and that they failed to comply with obligations under EU and international law. In particular, it stressed the absence of minimum conditions in reception centres in several Member states; the lack of a unified system of age determination and the use of invasive systems; unequal access to legal advice, mental health care and unequal education services in the states of the Union; non-compliance with the obligations arising from the Reception Conditions Directive; noncompliance with the objectives set by the 2010-201/4 Plan; lack of implementation of the provisions on family reunification and their impact on the increase in criminal activities of trafficking, sale and organised crime and the responsibility of states for several disappearances of migrant children. The report also denounced the merely formal incorporation into European and Member state law of the principle of the "best interests of the child" and its lack of application in many cases, including its perception as an obstacle to the effectiveness of migration policy. It was alarmed at the lack of external audits of state action and urged solidarity among members in sharing the burdens of childcare; it recognized the work of XGOs as benchmarks for the lack of real action by countries and the lack of support for local institutions from the Central Administrations of Member states; ${ }^{8}$ finally, it stated that the right to family reunification is applied to a limited extent to migrant children in the states of the $\mathbf{L}$ nion.

Shortly afterwards, the Comment on the state of implementation of the priority actions under the European Migration Agenda was adopted, the sixth annex of which refers to ongoing measures contributing to the protection of children in migration. ${ }^{8,5}$

This document sets out the measures, complementary to the Action Plan (2010-201/1), which the European Union has implemented since then and which follows the following axes: a) Additional and

8o European Directive $20133^{2}$ EU of the European Parliament and of the Council On common procedures for granting and withdrawing international protection. 26 June $2013 . \mathrm{L}$ I80 60 . Electronic text available here, accessed $2 弓$ July 2019.

$8_{1} \quad$ Supra 72.

82 Commission Implementing Regulation (EU) no 118 201/4 Amending regulation (ec) no $1560 / 2003$ laving down detailed rules for the application of council regulation (ec) no 3 亿3 2003 establishing the criteria and mechanisms for determining the member state responsible for examining an asy lum application lodged in one of the member slates by a third-country national. $3^{\circ}$ January 201/.8 February 201/439 I. Electronic text available here, accessed 2 J July 2019.

83 Authority of the IIouse of Lords, Children in crisis: unaccompanied migrant children in the EU'34 (IIL Iaper, London 2016) at 1 and go on. Electronic text available here, accessed 2. July 2019.

$8, \quad$ Ibidem at 98 . The report refers to the situation in the United Kingdom, however, affirms that the situation described occurs in most of the member state. Electronic text available here, accessed $2_{2}$ Juls 2019.

85 Communication from the Commission to the European Parliament, the European Council and the Council progress report on the implementation of the European Agenda on migration. COM(2016) 8 万f final $10 / 2$ 2or6. Electronic text available here, accessed $2 \jmath$ July 2019 . 
specific funding to achieve the objective of protecting migrant children in the European Union; b) Multilateral management through financial support to international organizations, organizations and agencies related to child and migration competencies; c) Collaboration and financial support to third sector organizations for the care of migrant children; (e) Specific budget allocation to the Asylum, Migration and Integration Fund for the early identification and protection of child victims of human trafficking and unaccompanied minors at risk of trafficking; f) Promotion in civil society and the University of the rights of migrant children and the fight against sale and trafficking through the fund through Erasmus program; g) Development of Guidelines on the realization of the best interests of the child including means for age determination and family tracing- by the European Immigrant Support Office; (i) Promote cross-border recognition of judicial decisions containing protective measures, including guardianship of unaccompanied and separated children through EU RJU ST; (j) Publication of guidelines and good practice guide on the application of rights to migrant children. ${ }^{86}$

In May and June 2016, the Commission published its proposal for the reform of the Dublin III Regulation. ${ }^{{ }^{7}}$ As stated by the Institution itself, the reform aims to ensure a better balance between responsibility and solidarity between Member states, promoling equal conditions for all applicants to avoid secondary movements of migrants within the territory of the European Union. Some of the proposed amendments have an impact on migrant children:

- It supports the training and preparation of those responsible for assessing the application, the child's condition of special vulnerability, as well as the existence of signs in the child of having been trafficked, sold, tortured or exploited. Those responsible must know the rights of the child in accordance with the United Vations Convention, and have been prepared to determine the primacy of the best interests of the child in the specific processes they must resolve. In this sense, European legislation is in line with the provisions of the General Comment regarding the preparation of personnel responsible for the reception and management of migrant children.

- The methods applied in the countries of the Union for determining age vary significantly in nature and scope. There are several questionable aspects in the practice of each state, but one of the most controversial is the repetition of medical tests to which they must submit, especially applicants for international protection. The Commission proposes that medical tests for age determination, carried out in one Member state, should be binding on the other states; this proposal is in line with the Committee's position on the Comment on migrant children for the sake of reducing the number of medical tests to which they are subjected.

86 Vote that according to article 27 of the European Directive 20n/95 EU about Refugees recognition, refugee children who have acquired long-term residence rights can access education under the same conditions as nationals. Electronic text available here, accessed 25 July 2019.

$8_{7}$ Proposal for a Regulation of the European Parliament and of the Council establishing the criteria and mechanisms for determining the Member state responsible for examining an application for international protection lodged in one of the Member states by a third-country national or a stateless person. COM (2016) 270 final. Electronic text available here, accessed $2 \jmath$ July 2019 . 
- It is proposed that a maximum period of $y$ days be set for the appointment of a legal guardian or representative within to days of the appointment of the guardian or representative to formalise the application in the best interests and welfare of the child. The maximum number of persons represented by the same person is not expressly determined, but the aim is to avoid a disproportionate number that would prevent the effective accompaniment of each child. In this sense, the reform directs what is established by the General Observation with regard to clear and transparent procedures for the migrant, but continues to rest the decision on a single instructor when the Observation requires a larger and more diverse number of professionals. The fact that representation can fall not only on a natural person but also on an organization raises doubts about the effectiveness of representation. However, it is established that the state that has appointed the child should also consider complaints lodged by the unaccompanied child in relation to his or her guardian.

- The reform proposal does not remove the application of the border procedure but is limited to situations where the unaccompanied child comes from an unsafe country, represents a danger to national security or public order, has misrepresented or omitted information to the authorities about his or her identity and circumstances, has submitted false or missing documentation, there are reasonable grounds to consider a third country as a safe country for the child. In this respect, the reform proposal is more demanding in relation to the obligation of the third state to ensure that it takes charge of the protection of the unaccompanied child.

- The Commission proposes an equalisation of rights and duties in the fields of employment, social security, education, health and integration programmes with European citizens, although these benefits would only be accessible once international protection has been recognised, but not to applicants. However, the Committee has stated unequiv oc ally that a child's living conditions and rights cannot be linked to the migratory status of his or her parents: access to such programmes cannot, therefore, depend on the slage of the proceedings at which the migratory status of his or her parents is at.

- The proposal allows states the possibility of limiting the freedom of movement within the state of persons receiving specific social benefits under the asylum sustem. This calls into question Article 26 of the Geneva Convention, which guarantees the freedom of movement of refugees and expressly prohibits persons enjoying international protection from living in a state of the European Union other than the one that granted it. Such a limitation would not directly contravene the General Comment, but may jeopardize the enjoyment of other rights connected with free movement.

- Improvements are also proposed with regard to the transfer of unaccompanied children between member countries. The proposed amendment strengthens the right to information and an effective remedy and expressly provides that decisions on transfer of responsibility are made in writing and guaranteeing the suspensive effect of the remedies. Ilowever, it limits the possibility of recourse to situations where there is a risk of inhuman or degrading treatment in the country of destination, when transfer decisions are based on criteria of dependency on relatives or minors and when the transfer decision has not considered family criteria. 
For its part, in November 2017, the European Parliament reached a provisional agreement pending approval by the Plenary on a compromise text adopted in the Parliament's Committee on Civil Liberties, Justice and Home Affairs (hereinafter LIBE) on the proposed amendment. ${ }^{88}$ The document was not adopted by Parliament's plenary session and is currently July 2019 still included in the socalled "outstanding issues". The report proposes substantial improvements from the perspective of the General Observation, among which the following should be noted:

- It indicates that the placement or confinement of children, whether or not accompanied by their families, is never in the best interests of the child and always constitutes a violation of the rights of the child and should therefore be prohibited. ${ }^{89}$

- It states unequivocally that in cases of transfer of a child to the responsible state, multidisciplinary assessment shall involve competent personnel specialized in the rights of the child and in child psychology and development, and shall also involve, at a minimum, the child's guardian and legal adviser..$^{\circ}$

- It provides that officials and staff serving the Vational Authorities of Member states shall receive training in Child Rights, Child Psychology and Child Development. This training will also include modules on risk assessment focusing on care and protection according to the individual needs of the child, with special emphasis on early identification of victims of trafficking and abuse, as well as training on good practices to prevent disappearances.

- It constitules separated minors as a distinct category of unaccompanied minors and proposes different specific attention for them..$^{91}$

The new European Parliament emerging from the May 2019 elections must decide whether it wishes to resume adoption of the report adopted in LIBE; if so, it would be a good document for the trialogue with the Commission and the Council; however, the Council has not yet reached formal agreement on its own text. Until a common agreement is reached which satisfies all Member states at Council level, interinstitutional trialogue negotiations cannot begin.

The impossibility of approving the reform of the CE AS and Dublin III in the previous legistature is premonitory of the difficulties that the issue will encounter in the present legislature, especially because of the fiere negotiation demonstrated by the Visegrad Group. In this sense, separating the specific legislative development of the protection of migrant children from the regulation of migration and international protection in general could be a solution.

\section{(c) Assessment of proposals on migralion management and their impact on migrant children}

In April 2017, the Communication from the Commission to the Council and the Parliament on the

\footnotetext{
88 Report on the proposal for a regulation of the European Parliament and of the Council establishing the criteria and mechanisms for determining the Member State responsible for examining an application for international protection lodged in one of the Member States by a third-country national or a stateless person. (COM(2016)o270 - C8-0173/2016 2016 or33(COD)). Electronic text available here, accessed 2 July 2019.

$8_{9} \quad$ Ibidem at Amendment 20. Electronic text available here, accessed 25 Juls 2019.

go Ibidem at Amendment roo. Electronic text available here, accessed 2j Julv 2019.

9r Ibidem at Amendment \&. Electronic text available here, accessed 2ృ July 2019.
} 
protection of migrant minors was adopted. ${ }^{92}$ The Communication, while commending the efforts made by Member states, recognized that the sharp and sudden increase in the number of migrant child arrivals had put pressure on national systems and administrations and revealed gaps and deficiencies in the protection of all categories of migrant children.

The objective was to propose a series of coordinated and effective measures to respond to the urgent gaps in the protection of minors and the needs they face once they arrive in Europe, ranging from identification, reception or the application of procedural safeguards to the implementation of durable solutions; to progress towards a comprehensive EU approach to migration management; and to ensure the effective protection of migrant minors with a view to strengthening cross-border cooperation.

A perspective is evident in the approach from migration management focused on the arrival of children seeking international protection towards a broader approach that includes irregular migration for economic reasons that seeks to protect children on a global scale, including in countries of origin and transit. It addresses several of the issues mentioned in the General Comment on the rights of migrant children. These include:

- The importance of registering all migrant children by laking steps to develop civil registration services in partner countries and on European territory;

- The need to strengthen the protection of migrant children during migration routes through crossborder cooperation and development cooperation;

- The adoption of a non-intrusive data collection system for children and the application of childfriendly and gender-sensitive approaches to the collection of fingerprints and biometric data. When the results are inconclusive, the person is presumed to be a minor, being given the benefit of the doubt in line with EU legislation. However, it does not welcome the ultimate spirit of the General Comment which indicates that an age determination procedure should only be used as a last resort: this means that they have to start with an interview and that the identity documents that they provide (passports, birth certificates, consultation registration certificates, etc.) are alway s considered valid, unless there is proof to the contrary;

- The negative impact of detention on minors is recognized and the search for alternative systems is encouraged; however, this is not prohibited, but is limited to exceptional circumstances, when strictly necessary, only as a last resort, for the shortest possible period of time and in no case in prison facilities;

- The establishment of effective monitoring systems at national level is promoted and should also contribute to the good functioning of reception centres, ensuring that commercial interests (in the case of centres run for profit) do not prevail over the protection of minors. Ilowever, the independent nature of the supervisory systems proposed in the General Comment is not envisaged;

- It stresses the importance of formal education being received irrespective of their status or that of their parents, and of it being effective and allowing them, in accordance with the rules in force in each state, official recognition of the studies carried out and the continuity of their training, although children will

\footnotetext{
$9^{2}$ Communication from the Commission to the European Parliament and the Council The protection of children in migration SII D) (2017) 129 final. COM (2017) 21 final. Electronic tevt available here, accessed 2 July 2019.
} 
have access to education, "depending on the length of their stay". On the other hand, it also makes no reference to the separation between units of the administration responsible for the provision of services and units dedicated to the implementation of the migration control policy requested by the Committee in the General Comment;

- Early and effective access to inclusive formal education is promoted, and the training of teachers to prepare them to work with children from diverse backgrounds is a key factor for integration. Ilowever, no mention is made of the need to introduce specific aspects into school curricula on migration flows and the rights of migrants, an issue advocated by the General Comment; however, it should be recalled that the EU has no competence to determine either the content or the scope of national educational provisions.

- It promotes family tracing and reunification family unit procedures by requiring states to make full use of cooperation channels through the central authorities provided for in the Brussels II bis Regulation on parental responsibility and the creation of a European guardianship network. It should be remembered that, according to the ECIIR, the family is the natural environment for the growth and well-being of a child. However, if a family cannot provide adequate care and protection it may be necessary to move to an alternative care environment. This separation interferes with respect for family life and therefore the alternative care regime can only be a temporary measure and that the child should ultimately be reunited with his her family in compliance with Article 8 of the ECIIR. ${ }^{93}$ In this respect, it should be recalled that the EU must apply the case law of the Court when it states - in Olsson $\checkmark$ Sweden - that children are placed in foster care, they retain their right to maintain contact with their parents so that the child can be effectively reintegrated into their family. ${ }^{91}$

- Decisions to return children to their countries of origin must respect the principles of non-refoulment and the best interests of the child; they must be based on case-by-case assessments and follow a fair and effective procedure guaranteeing their right to protection and non-discrimination. Priority should be given to better cooperation with countries of origin through, inter alia, improved family tracing and reintegration conditions.

Owning to the change in the migration scenario -from a fundamentally refugee crisis between 2013 and 2016 to the current migration crisis unparalleled since the Second W orld W ar-and with strong political tension in some of its Member states over speeches calling for absolute border control and the criminalisation of irregular migration, the European $\mathrm{Union}$ is once again immersed in a complex situation. The anti-European discourse of some governments in the south and the fear that it will spread to other states - has led to a greater willingness on the part of the countries in the north of the Union to respond to the Commission's requests for cooperation. Perhaps, this has facilitated the resettlement of migrant children arriving in Greece and Italy ${ }^{95}$ but, on the contrary, it has increased the stigmatisation of the

93 K I v. Finland, ECIIR (2003) Series A \o. 2775 195 . Electronic text available here, accessed 25 July 2019.

91 Olsson v. Sweden, ECIIR (1988) Series A Vo. 10/9 $66_{j} 8$. Electronic text available here, accessed 2j. July 2019 ; also, Eriksson v. Suecia, ECIIR \o. 13733 8 8 . Electronic text available here, accessed 2 July 2019.

95 The statisties of the European Commission in April 2019 seem to strive to show the work of the European States to alleviate the migratory pressure in Italy and Greece: The data reflects that more than $34^{\circ}$ of the reseltlements of 
migratory phenomenon.

Migration remains a problem for the European Union, although it has decreased in the last year. Irregular migrants continue to cross the external and internal borders of European countries. It is paradoxical to observe that while national governments of state members continue, for the most part, to manage the situation autonomously under their own standards and particular interest, the media hold the European Union responsible for the lack of adequate response.

While there is no progress on reform agreements, European leaders are exploring parallel solutions such as the one adopted at the June 2018 European Council when it was proposed to create regional controlled centres and landing platforms in third countries for migrants rescued in naval operations. ${ }^{{ }^{6}}$

Of course, it is premature to analyse the conclusion of the European Council, which is not very specific, but it is possible to highlight some elements in relation to the rights of migrant children:

- It should be stressed that the Council Conclusions document does not include any reference to migrant children but clearly the initiative to get ahead would affect them;

- The aim of the proposal is framed within migration reduction strategies by seeking to reduce the motivation of migrants and therefore their exposure to the risk of crossing -which would have very positive effects in the case of unaccompanied minor- and to favour "a fast and safe processing" of migrants' applications, which should benefit refugee children and applicants for international protection;

- In principle, European Union law does not prevent the establishment of controlled centres on its territory unless it affects the inalienable sphere of private life and fundamental rights and freedoms; however, it is clear that there is a high risk of segregation and stigmatisation which would be contrary to the Convention on the Rights of the Child;

- The usefulness of the measure with regard to migrants already in the territory of a Member state is questionable, since the transfer to such a centre could only take place on a voluntary basis, since their detention and transfer is not admissible simply because they are migrants. In the case of children, it would only be admissible if the transfer presents advantages from the perspective of their superior interest and it would be questionable -little aesthetic, at best- if the advantage argued was family reunification in the centre;

- With regard to the transfer of rescued persons to landing platforms within the European Union, European legislation on asylum and international protection is fully applicable to them. With regard to children, the question does not differ from what has been said for controlled centres: it is worth asking whether these facilities will be able to receive all the means necessary to meet their needs. Pending the final design of these platforms, their compatibility with the right not to be held against their will simply because they are migrants is questionable;

- With regard to the installation of landing platforms for migrants outside European territory is important to remark its connection with a new European Union naval operation "for research and

unaccompanied children came from these countries. Electronic text available here, accessed 2ృ July 2019.

$9^{6}$ European Council Conclusion (28 June 2018). Electronic lext available here, accessed 25 July 2019. 
rescue" in accordance with the new rules that would be adopted in the next years. Considering that European Council would be proposing the creation of disembarkation platforms and controlled centres in relation to migrants rescued in the context of search and rescue at sea operations (hereinafter, S AR), the International Law of the Sea will be applicable. ${ }^{97}$ In this situation the key question would be to determine the place where the rescue of migrants took place:

(i) Migrants rescued in the territorial waters of third states are not under the control and jurisdiction of the Member states of the Union and, therefore, are not subject to European Union asylum law, but are subject to the law of the responsible third state. ${ }^{8}$ However, the principle of non-refoulement would prevent people from disembarking in a country where they could suffer inhuman and degrading treatment. In any case, given that people are disembarked by the European Union, all platforms should comply with the guarantees contained in the Convention on Refugees and the European Convention on Ituman Rights. In the other hand, if the disembarking is not possible, the migrant children must remain under protection of the European Union or the state pavilion until their finally distribution by agreement between the member states or relocated in a third safe country. The disembarking cannot forget the principles of best interest of the child and the further family reunification.

(ii) Migrants rescued at high sea are not subject to European Union law unless they have been rescued by state vessels flying the flag of a Member state or shipping under European Union international civil or military operation. Thus, in legal certainty, they could be transferred to platforms located both inside and outside European territory, as long as these were considered safe by the Union.

(iii) Migrants rescued within the territorial waters of the Union -that is to say, in its territorial sea or contiguous zone by state vessels of Member states- cannot be sent to platforms outside the European Union without first having access to asy lum procedures in the European Union and

97 The United Vations Convention of the Law of the Sea codified the longstanding tradition in the customary International law of the sea of duty of rescue people in distress (Article 98 U VLOS 1982 . Electronic text available here, accessed 2j. July 2019). In 1989 , Article ro of the Convention on Salvage stablished that Every master is bound, so far as he can do so without serious danger to his vessel and persons thereon, to render assistance to any person in danger of being lost at sea (Convention on Salvage of 1989 Electronic text available here, accessed 25 July 2019). The article also, prevent that states parties shall adopt the measures necessary to enfore that duty by the vessels under its pavilion. The duty to provide assistance encompasses asylum-seekers and refugees, as it applies in all maritime zones and to every person in distress without discrimination. Ilowever, the specific legal framework governing rescue at sea does not apply to interception operations that have no search and rescue component. The obligation to provide assistance is provided for in the r974 International Convention for the Safety of Life at Sea (hereafter, SOL AS). According to Regulation $33^{(1)}$ of Chapter $\checkmark$ the master of a ship at sea in the position to assist persons in distress is bound to proceed to their assistance. The Governments of states parties are responsible for ensuring that necessary arrangements are made for distress communication and co-ordination in their area of responsibility and for the rescue of persons in distress at sea around its coasts. These arrangements shall include the setting up, operation and maintenance of S IR facilities. In 200/, the amendment of SOL AS included additional obligations upon states parties to cooperate in order to ensure that ships' masters are allowed to disembark rescued persons at a place of safety, irrespective of the nationality or status of those rescued.

$9^{8}$ Iny agreement that the European Union reaches with a third State for the landing of migrants must respect International Ituman Rights Law. 
knowing the full outcome of their application for international protection. Failure to do so would be tantamount to a hot return.

If the proposal goes ahead, migrants would be located in these spaces in standlby until the final decision about their entry in the territory of the Union: either through a positive assessment of their application for asylum, for international protection or until they obtain a work permit; the rest would remain there until they are returned to their states of origin. Undoubtedly, the European Union would be responsible for ensuring that throughout the asylum procedure the guarantees set out in the Convention on the Rights of the Child and in the General Comment on migrant children (i.e. the right to be heard, to have a guardian, consideration of the best interests of the child, etc.) as well as the obligation to provide the basie services due to them (education, health, familt life, personal development, etc.) are complied with.

It seems a complex solution in operational terms whose failure could lead to objective international responsibility on the part of the European Union. On the other hand, the option of outsourcing the management of such centers and platforms through third States or International Organizations seems a possibility but would not elude the European Union from a possible responsibility in vigilando for any violation of human rights.

This is a legally complex operation that involves risks from a technical and media point of view a sensitive issue considering the reduced social eredit in the Union on this issue ; however, the European Union would be more autonomous and would obtain the not inconsiderable advantage of no longer being subordinated to the action of states and punctual political party interest- in the implementation of migration policy.

\section{(E) CONCLUSIONS}

Migration has been one of the major concerns of the international community since r 970 ; since then it has alternated between successes -primarily in relation to the rights granted to migrants- and major failures in the anticipation and control of migratory flows and trafficking. For the last 20 years, migration has been at the heart of studies and the international agenda. The recent negotiations to promote a Global Compact for safe, regular and stable migration have not received the support of the main receiving states. The evolution of the number of migrants and the countries of origin and destination of migrations seems to bring the multilateral negotiations to a structural antagonism.

International organizations and $\mathrm{NGO}$ s in the migration sector have long warned about the drama of children facing migration, especially if it is not done safely.

In 2017, after describing the current state of migratory flows as a humanitarian catastrophe for children, the Committee on the Rights of the Child agreed to elaborate, with the Committee on Migrant Workers, General Comment 22 and 23 on the rights of the child in the context of international migration. Both General Comments do not create new rights, but concretise the rights set out in the Convention on the Rights of the Child in the context of international migration.

The arrival of migrants on the territory of the European Union is not recent; however, a combination 
of various factors has led to a remarkable increase in the volume of arrivals since 20n. The increase in immigration coupled with economic difficulties has exacerbated the anti-immigration discourse in several Member slates.

The European Union is responsible for migration and asylum. In recent years it has developed its action on migrant children, particularly unaccompanied migrant children: it has established action plans, adapted the asy lum reception sy stem and improved the standards for the treatment of children by states at the Union's external borders. Ilowever, the reports are critical of the results achieved and, reform after reform, it is emphasised that essential issues such as the best interests' principle have been accepted only for formal purposes.

Reports show that the treatment of migrant children is unequal depending on the member country in which they are found, and that there is a need for external and independent verifiers to audit state performance.

It is paradoxical to observe that while states do not fulfil their commitments of solidarity in the distribution of migrants, it is the European Union that takes the lion's share of the criticism.

Despite the criticism regarding the hidden molives of the legislative reforms in the area of migration, the fact is that the Commission has made a significant effort to improve legistation on the protection of migrant children, and particularly in the case of unaccompanied minors. The conversion of the European Asylum Support Office (E ASO), which will become the European Union Asylum Agency and the extension of its mandate, seems to open the way for the verification of Member states' compliance with their obligations under Union law.

This effort does not imply that European legislation and the actions of its Member states are in accordance with the General Observation on the rights of the child in the context of international migration. The European Union has abstained from introducing some issues of focus: on the one hand, the separation between units of the administration dedicated to the provision of basie services and those dedicated to the execution of migration policy; on the other hand, the Union is unable to obtain from its Member states a common position on the degree of openness in migration policies under the premise that, those especially repressive, may constitute violations of human rights within the framework of International Law and the European Union's own Law.

While the tension between Member states increases and in the absence of an agreement for the approval of the Dublin IV Regulation, internal political tensions and the advent of governments that openly postulate against immigration have led the European Council to look for alternative measures for migration management through the establishment of controlled centres and platforms for the disembarkation of migrants in third states. So far its formulation warns of a lack of focus on the rights of migrant children.

The absence of available information does not allow for detailed analy sis. Valued the disincentive effect on migrants and its impact on the number of vietims the implementation of the measure raises doubts about its compatibility with the Convention on the Rights of the Child and its General Comment on the rights of the child in the context of international migration. On the other hand, the extension of the stay in 
the centres and disembarkation platforms could lead to a progressive invisibility of migrant children; undoubtedly the greatest damage to this particularly vulnerable group and a step back in the compliance with International Law of Iluman Rights. 